\title{
Hubungan antara Trait Mindfulness dan Kesepian pada Orang Dewasa Awal
}

\author{
MUHAMMAD FAHIZZA AMRU \& TRI KURNIATI AMBARINI* \\ Fakultas Psikologi Universitas Airlangga
}

\begin{abstract}
ABSTRAK
Kesepian telah dilaporkan mengalami tren peningkatan. Salah satu alasan yang diduga kuat menjadi penyebabnya adalah terjadinya wabah virus corona. Penelitian ini bertujuan untuk mengetahui peran trait mindfulness terhadap kesepian pada orang dewasa awal. Penelitian menggunakan metode kuantitatif dan desain korelasional. Sebanyak 169 orang dewasa awal berusia 20-40 berpartisipasi dalam penelitian ini. Perolehan data menggunakan skala multidimensi Five-Facets of Mindfulness (FFMQ) dan The University of California, Los Angeles Loneliness Scale Version 3 (UCLA). Analisis dilakukan dengan teknik korelasi Pearson dengan metode bootstrap menggunakan 5000 sampel bootstrap. diketahui bahwa trait mindfulness memiliki hubungan negatif secara signifikan dan berkekuatan sedang dengan kesepian $(r(5000)=-0,495 ; 95 \%$ CI $[-0,368 ;-0,608] ; p<0,000)$. Hasil ini menunjukkan bahwa semakin tinggi trait mindfulness pada individu, maka semakin rendah kecenderungannya untuk mengalami kesepian.
\end{abstract}

Kata kunci: dewasa awal, kesepian, trait mindfulness

\section{ABSTRACT}

Loneliness has been reported to be on an increasing trend. One reason that is strongly suspected to be the cause is the coronavirus outbreak. The aim of this study was to examine the role of trait mindfulness on loneliness in early adults. This research uses quantitative methods and correlational designs. A total of 169 early adults aged 20-40 participated in the study. Data were obtained using the Five-Facets of Mindfulness (FFMQ) and The University of California, Los Angeles Loneliness Scale Version 3 (UCLA). Bootstrapped Pearson correlation was carried out using 5000 bootstrap samples, it is known that trait mindfulness has a significant moderate negative correlation with loneliness $(r(5000)=-0,495 ; 95 \%$ CI [$0,368 ;-0,608] ; p<0,000)$. The result indicates that being more mindful leads to lower loneliness.

Keywords: early adults, loneliness, trait mindfulness

Buletin Penelitian Psikologi dan Kesehatan Mental (BRPKM), 2021, Vol. 1(2), 1064-1074

*Alamat korespondensi: Fakultas Psikologi Universitas Airlangga, Kampus B Universitas Airlangga Jalan Airlangga 4-6 Surabaya 60286. Surel: tri.ambarini@psikologi.unair.ac.id

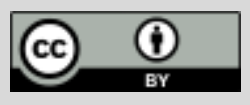

Naskah ini merupakan naskah dengan akses terbuka dibawah ketentuan the Creative Common Attribution License (CC-BY-4.0) (http://creativecommons.org/licenses/by/4.0), sehingga penggunaan, distribusi, reproduksi dalam media apapun atas artikel ini tidak dibatasi, selama sumber aslinya disitir dengan baik. 


\section{PEN D A H U L U A N}

Kontak sosial merupakan kebutuhan krusial bagi manusia yang merupakan makhluk sosial. Begitu pentingnya kontak sosial hingga kesejahteraan hidup individu bergantung pada kemampuannya untuk memenuhi kebutuhan tersebut. Gagasan akan pentingnya kontak sosial dapat dipahami melalui suatu fenomena yang disebut sebagai kesepian. Kesepian bukanlah merupakan kondisi klinis maupun patologis dan justru merupakan fenomena normatif sebagai manusia (Akin, 2010). Meski demikian, kesepian tetap merupakan pengalaman negatif yang perlu diatasi. Kesepian diartikan sebagai perasaan menekan yang dihasilkan dari adanya persepsi bahwa kebutuhan sosial individu tidak terpenuhi oleh kuantitas atau terutama kualitas dari hubungan sosial yang dimiliki (Hawkley \& Cacioppo, 2010). Menurut model yang diajukan oleh (Hawkley \& Cacioppo, 2010), perasaan kesepian setara dengan perasaan tidak aman, hal ini menyebabkan munculnya perilaku hypervigilance atau kewaspadaan berlebih akan ancaman sosial yang kemudian menghasilkan bias kognitif negatif yang menghambat interaksi sosial. Pada titik ini, bias kognitif dapat memunculkan siklus yang memperkuat pengalaman kesepian melalui stres, kecemasan, harga diri yang rendah yang muncul akibat hubungan sosial yang tidak memuaskan. Pada akhirnya kesepian dapat berdampak pada masalah kesehatan yang lebih serius.

Fenomena kesepian tercatat mengalami peningkatan yang signifikan selama beberapa tahun terakhir. Sebuah studi pendahuluan di Amerika Serikat menunjukkan adanya peningkatan kesepian yang substansial sejak kuartil awal tahun 2020. 36\% dari seluruh responden melaporkan kesepian frekuensi pengalaman kesepian yang tinggi. 68\% dari individu berusia 18-25 tahun dan Ibu dengan anak melaporkan kesepian tingkat tinggi (Weissbourd dkk., 2021). Mendukung hasil tersebut, sebuah penelitian di Amerika Serikat juga menunjukkan bahwa sejak kuartil awal tahun 2020 terjadi peningkatan tingkat kesepian pada individu dewasa awal (18-35 tahun), dengan 49\% partisipan memiliki kesepian tingkat tinggi (Horigian dkk., 2021). Di Italia, individu dewasa awal mengalami peningkatan kesepian khususnya bagi mereka yang sedang dalam kebutuhan perawatan kesehatan mental (Marchini dkk., 2021). Hwang dkk. (2020) mencatat bahwa prevalensi kesepian diketahui sebesar $10-40 \%$ di seluruh Amerika Serikat, China, dan negara-negara Eropa, hal ini digambarkan sebagai "behavioral pandemic". Tren peningkatan juga ditemukan di Indonesia. Dalam penelitian yang dilakukan oleh perusahaan media sosial Snap Inc. yang melibatkan 2.500 responden ditemukan bahwa $72 \%$ responden merasa tidak lagi dekat dengan teman-temannya, dan kesepian meningkat sebesar 18\% (Desk, 2020). Penelitian lain dari Peltzer \& Pengpid (2019) menemukan kesepian diketahui memiliki prevalensi secara merata pada populasi umum dengan puncak yang relatif lebih tinggi pada remaja akhir atau dewasa awal dan dewasa akhir di Indonesia. Tren peningkatan kesepian ini diatribusikan kepada peristiwa pandemik COVID-19.

Persoalan kesepian yang meningkat, sebagaimana telah disebutkan sebelumnya, juga terjadi pada individu dewasa awal. Hal tersebut dapat terjadi karena individu yang memasuki fase dewasa awal dihadapkan dengan tuntutan untuk menjadi orang dewasa dari fase sebelumnya yaitu remaja seperti tuntutan pekerjaan atau karir serta masalah terkait finansial. Selain itu, masa dewasa awal juga merupakan fase penting untuk memenuhi krisis psikososial, yaitu intimacy vs. isolation (Newman \& Newman, 2015), sehingga keberhasilan pada tahap ini akan menentukan kemampuan individu untuk menjalin hubungan yang mendukung dan terbuka dengan orang lain.

Banyak penelitian yang terus membuktikan dampak merugikan dari kesepian. Dampak tersebut meliputi kesehatan fisik hingga mental. Kesepian berkorelasi dengan fungsi kognitif yang lebih rendah, memiliki satu atau lebih kondisi kesehatan yang kronis, mengalami stroke, gejala depresi, gangguan tidur, gangguan terkait tidur, dan kepuasan hidup yang rendah (Peltzer \& Pengpid, 2019). Sebuah meta analisis menunjukkan bahwa kesepian memiliki hubungan positif dengan psikosis (Rocha dkk., 2018), 
hasil penelitian tersebut didukung dengan penelitian serupa yang dilakukan di Indonesia (Audinia, 2019), kesepian juga diketahui memiliki hubungan yang kuat dengan peningkatan risiko alzheimer (Sundström dkk., 2020), serta demensia dan gangguan performa kognitif juga penurunan fungsi kognitif dari waktu ke waktu (Gow dkk., 2007). Peningkatan hypervigilance akan ancaman sosial yang kemudian menimbulkan perilaku menghindar dari ancaman sosial tersebut (Bangee dkk., 2014), hal ini tentunya dapat mengganggu interaksi sosial yang sehat dan memperkuat pengalaman kesepian.

Lim dkk. (2020) melalui kajian literaturnya menerangkan bahwa kesepian diinisiasi oleh faktor pemicu dan kualitas pengalaman kesepian dipengaruhi oleh tiga faktor utama, yaitu lingkungan sosial, kesehatan, dan demografi. Lingkungan sosial mencakup komunikasi digital dan faktor-faktor yang berkaitan tempat kerja (workplace). Kesehatan meliputi kesehatan fisik, mental, kognitif, otak, biologi, dan genetik, beberapa kondisi seperti masalah atau gangguan pada area tertentu dapat menyebabkan pengalaman kesepian. Kemudian, faktor demografis mencakup hal seperti usia dan status sosial serta ekonomi individu. Sementara itu. Coşan (2014) mencatat bahwa karakteristik personal misalnya malu, tingkat kepercayaan diri yang rendah merupakan karakteristik yang dapat menyebabkan munculnya kesepian pada seseorang. Disisi lain, sikap terbuka dapat berperan menjadi faktor protektif yang berkaitan dengan karakteristik personal. Menurut penelitian Lindsay dkk. (2019) mengembangkan sikap terbuka terhadap pengalaman saat ini telah dibuktikan dapat menurunkan pengalaman kesepian. Kualitas sikap yang terbuka terhadap pengalaman saat ini dapat dijelaskan melalui ciri kepribadian yang disebut sebagai trait mindfulness.

Trait mindfulness atau disposisional mindfulness secara khusus mengacu pada pola-pola umum dalam perilaku mindfull yang tidak terikat oleh ruang dan waktu. Sedangkan, state mindfulness mengacu pada sejauh mana tingkat mindfulness individu pada waktu tertentu (Sala dkk., 2019). Keduanya merupakan turunan dari konsep utama yaitu mindfulness, yang digambarkan sebagai pola kognitif serta mencakup state dan trait (Sternberg, 2000).

Mengacu pada instrumen Five Facets of Mindfulness atau FFMQ, Trait mindfulness secara multidimensional terdiri dari 5 aspek antara lain: (1) observing; menyadari penuh berbagai macam stimulus, seperti fenomena internal maupun eksternal dengan peka dan memberikan perhatian atau fokus pada elemen-elemen stimulus seperti lokasi, intensitas, serta durasi (2) describing with words; pelabelan atau pengungkapan pengalaman secara tepat (3) acting with awareness: terlibat secara utuh dalam segala bentuk aktivitas (4) non-judging experience: tidak melakukan penghakiman terhadap pengalaman dengan cara penerimaan (5) non-reactivity to inner experience: proses menerima, memahami, dan merasakan secara utuh pengalaman yang sedang dialami sebelum kemudian melakukan tindakan tertentu (Baer dkk., 2006). Keseluruhan dimensi menjelaskan proses mindfulness terhadap individu untuk peka terhadap situasi atau fenomena internal dalam diri dan eksternal di sekitarnya. tidak melakukan pelabelan yang berlebihan, mempertahankan perhatian penuh pada sensasi saat ini (undivided attention) dan menerima tanpa penilaian berlebih maupun mengkritik diri sendiri (Baer dkk., 2004).

Sha'ked \& Rokach (2015) menjelaskan bahwa individu yang mindful memiliki kesadaran akan pengalaman internal maupun eksternal dirinya. Hal tersebut menyebabkan individu menjadi lebih mampu untuk mengatasi respon-respon fisik maupun psikologis yang berkaitan dengan kesepian seperti peningkatan kortisol ataupun kecemasan. Selanjutnya, semakin mindful individu maka ia akan memiliki kemampuan regulasi atensi yang lebih baik sehingga kecenderungan individu yang kesepian untuk melakukan perbandingan sosial serta menginterpretasikan situasi sosial secara bias akan 
menurun. Kemudian, semakin mindful individu maka dirinya juga akan dapat meningkatkan persepsi yang lebih positif terhadap diri sehingga menghasilkan self-esteem yang lebih baik dan akhirnya berdampak pada rendahnya tingkat kesepian yang dialami

Berdasarkan pemaparan tersebut diketahui bahwa terjadi tren peningkatan fenomena kesepian di berbagai belahan dunia termasuk di Indonesia pada individu dewasa awal. Peningkatan tersebut tentunya memunculkan kewaspadaan akan dampak negatif dari kesepian terhadap kesehatan. Penelitian di Indonesia mengenai kesepian banyak menggunakan variabel sosio-demografis serta berfokus pada konsekuensi negatif dari kesepian, sehingga disinilah penelitian ini diharapkan dapat berperan. Penelitian ini bertujuan untuk mengetahui apakah terdapat hubungan antara trait mindfulness dan kesepian pada orang dewasa awal.

\section{Desain Penelitian}

\section{MET O D E}

Penelitian ini menggunakan pendekatan kuantitatif cross-sectional dengan teknik survei. Teknik pengumpulan data dilakukan menggunakan survei online dengan media limesurvey. Berdasarkan tujuannya penelitian ini merupakan jenis penelitian eksplanatori dan korelasional sehingga penelitian ini bertujuan untuk menguji hipotesis korelasi antara beberapa variabel, dalam hal ini yaitu trait mindfulness dan kesepian pada orang dewasa awal.

\section{Partisipan}

Metode pengambilan sampel pada penelitian ini adalah non-probability sampling dengan teknik purposive sampling untuk mendapatkan sampel dengan karakteristik sesuai dengan tujuan penelitian. Adapun kriteria partisipan dalam penelitian ini adalah berjenis kelamin laki-laki atau perempuan, berusia dewasa awal dengan usia 20 sampai 40 tahun, selain itu penelitian ini juga mengumpulkan data demografis lain dari responden, yaitu status pernikahan dan tingkat pendidikan. Penjelasan dan persetujuan mengenai penelitian telah diinformasikan secara tertulis pada kuesioner sebelum responden berpartisipasi dalam penelitian ini.

Penelitian ini mengumpulkan sejumlah 169 responden $\left(M_{\text {usia }}=25,31 ; S D_{\text {usia }}=5,72\right)$ untuk menguji hipotesis penelitian. Berdasarkan jenis kelamin, sebagian besar partisipan adalah perempuan $(78,10 \%)$ dan lainnya adalah laki-laki (21,90\%). Kemudian berdasarkan status pernikahan partisipan yang berstatus lajang mendominasi sebanyak 118 orang (69,80\%), sedangkan partisipan yang menikah sebanyak 51 orang $(30,20 \%)$. Selanjutnya, berdasarkan tingkat pendidikan komposisi partisipan secara berurutan dari jumlah terbanyak adalah partisipan dengan pendidikan D4/S1 sebanyak 74 orang $(43,80 \%)$, pendidikan menengah atau SMA sebanyak 71 orang (42\%), pendidikan S2 sebanyak 16 orang (9,50\%), pendidikan D1/D2/D3 sebanyak 7 orang (4,10\%), pendidikan S3 sebanyak 1 orang $(0,60 \%)$.

\section{Pengukuran}

Alat ukur yang dipilih untuk mengukur variabel trait mindfulness adalah skala Five-Facets of Mindfulness (FFMQ) yang dikembangkan oleh (Baer dkk., 2006). Alat ukur yang digunakan dalam penelitian ini telah diadaptasi ke dalam Bahasa Indonesia oleh Fourianalistyawati dkk. (2016). Skala FFMQ meliputi 5 dimensi yaitu observe, describe, act with awareness, non-judging, dan non-reactivity. Penyekoran total skor seluruh dimensi dilakukan untuk menguji hipotesis penelitian, akan tetapi uji korelasi juga dilakukan terhadap masing-masing dimensi tersebut. Skala FFMQ merupakan skala self-report yang 
memiliki total 39 pernyataan dengan 19 pernyataan unfavorable. Tersedia 5 pilihan respon berskala likert (1="tidak pernah, 5="selalu"), penyekoran terbalik dilakukan pada pernyataan unfavorable. Validitas alat ukur didasarkan pada skor corrected item-total correlation untuk setiap dimensi FFMQ, skor bervariasi antara 0,262 hingga 0,746. Reliabilitas alat ukur didasarkan pada skor koefisien alpha untuk setiap dimensi, skor berkisar antara 0,632 hingga 0,854. Dengan demikian, uji validitas dan reliabilitas menggunakan teknik tersebut menghasilkan koefisien yang dapat diterima.

Alat ukur yang dipilih untuk mengukur pengalaman kesepian adalah The University of California, Los Angeles Loneliness Scale Version 3 (UCLA) yang dikembangkan oleh Russell (1996). Alat ukur yang digunakan telah diadaptasi ke dalam Bahasa Indonesia oleh Mare (2015). UCLA merupakan skala berjenis self-report. UCLA memiliki 20 butir dengan 9 butir pernyataan unfavorable. Terdapat 4 pilihan respon pernyataan ( $1=$ "tidak pernah, $4=$ "sering"), penyekoran terbalik dilakukan pada pernyataan unfavorable. Validitas didasarkan pada skor corrected item-total correlation menunjukkan hasil yang cukup baik dengan skor bervariasi dari 0,402 hingga 0,738. Sedangkan reliabilitas berdasarkan koefisien alpha diperoleh hasil yang baik $(\alpha=0,91)$.

Uji korelasi pada penelitian ini dilakukan dengan dua cara. Pertama, mengorelasi antara skor total variabel trait mindfulness dan skor total variabel kesepian untuk menguji hipotesis penelitian. Kedua, mengorelasi antara skor total masing-masing dimensi trait mindfulness dan skor total variabel kesepian. Penjumlahan skor tersebut menghasilkan data interval. Kemudian, untuk menentukan apakah uji korelasi parametrik dapat digunakan, maka dilakukan uji asumsi yaitu uji normalitas dan linearitas untuk setiap variabel.

Uji normalitas menggunakan tes Shapiro-Wilk (SW), dan z-test menggunakan skor skewness dan kurtosis. Berdasarkan tes SW terdapat dua variabel yang menyimpang dari distribusi normal, yaitu variabel kesepian dan dimensi non-reactivity $(p<0,05)$. Sedangkan, berdasarkan $z$-test skewness dan kurtosis diketahui bahwa distribusi normal pada seluruh variabel dapat diasumsikan karena skor $z$ yang diperoleh tidak melebihi nilai 3,29 atau $-3,29$ untuk $N=196$. Kemudian, uji linearitas dilakukan berdasarkan skor deviasi linearitas melalui tes ANOVA. Berdasarkan hasil uji linearitas tersebut diketahui bahwa seluruh variabel dapat dijelaskan dengan baik menggunakan model linear $(p>0,05)$

\section{Analisis Data}

Penelitian ini bertujuan untuk menguji hubungan antara dua variabel penelitian. Maka, analisis data akan dilakukan dengan cara uji korelasi. Teknik korelasi yang digunakan untuk menguji hipotesis penelitian adalah uji parametrik pearson dengan metode bootstrap. Proses analisis data dilakukan menggunakan perangkat lunak SPSS Statistic for Windows versi 22.0 tahun 2013 dan Minitab 19.2020.1.

\section{HAS IL PENELITIAN}

\section{Analisis Deskriptif Sampel Penelitian}

Analisis deskriptif dilakukan pada seluruh sampel untuk mengetahui gambaran umum terkait masingmasing variabel penelitian pada sampel, serta untuk memperoleh data deskriptif berdasarkan karakteristik partisipan. Total sampel yang diperoleh dalam penelitian ini adalah 169 orang $\left(M_{\text {usia }}=25,31 ; S D_{\text {usia }}=5,72\right)$. Pertama, berdasarkan hasil analisis deskriptif yang telah dilakukan, pada variabel kesepian diperoleh nilai terendah sebesar 21, tertinggi sebesar 71 dan standar deviasi sebesar 10,620 . Sedangkan pada variabel trait mindfulness skor terendah yang diperoleh adalah 75 dan tertinggi adalah 155 dengan standar deviasi sebesar 14,137. Kedua, rata-rata kesepian ditinjau dari karakteristik 
sampel penelitian antara lain, berdasarkan jenis kelamin nilai rerata laki-laki lebih tinggi yaitu 41,81 dan 38,93 untuk perempuan. Lalu, berdasarkan tingkat pendidikan adalah 40,96 untuk pendidikan menengah (SMA) dan 38,93 untuk pendidikan tinggi (D1-S3). Selanjutnya, berdasarkan status pernikahan adalah 40,60 untuk individu yang berstatus lajang dan 37,88 bagi individu yang berstatus menikah. Ketiga, rata-rata trait mindfulness ditinjau dari karakteristik sampel antara lain, pada laki-laki adalah 121,11 dan 121,71 untuk perempuan. Lalu, ditinjau dari tingkat pendidikan adalah 118,15 bagi individu dengan pendidikan menengah (SMA) dan 124,06 untuk individu dengan pendidikan tinggi (D1S3). Terakhir, ditinjau dari status pernikahan, trait mindfulness lebih rendah pada individu lajang dengan rata-rata 119,70 dan lebih tinggi pada individu yang menikah dengan rata-rata 125,92.

\section{Uji Korelasi}

Uji korelasi dilakukan menggunakan teknik korelasi pearson dengan metode bootstrap. Sebanyak 5000 sampel bootstrap digunakan dalam penelitian ini. Uji korelasi dilakukan pada skor total keseluruhan dimensi trait mindfulness dengan kesepian untuk menguji hipotesis penelitian, juga dilakukan pada masing-masing dimensi trait mindfulness (observe, describe, act with awareness, non-judgement, nonreactivity) dengan kesepian.

Hasil uji korelasi antara trait mindfulness dan kesepian menunjukkan bahwa terdapat hubungan negatif yang signifikan dan berkekuatan sedang $(r(5000)=-0,495 ; 95 \%$ CI $[-0,368 ;-0,608] ; p=0,000)$. Selanjutnya, hasil uji korelasi antara masing-masing dari kelima dimensi trait mindfulness dan kesepian antara lain, pertama, dimensi observe dan kesepian menunjukkan hubungan yang tidak signifikan $(r(5000)=-0,043 ; 95 \%$ CI $[0,134 ;-0,214] ; p=0,577)$. Kedua, dimensi describe dan kesepian menunjukkan hubungan negatif yang cenderung lemah dan signifikan $(r(5000)=-0,360 ; 95 \%$ CI $[-0,227 ;-0,483]$; $p=0,000)$. Ketiga, dimensi act with awareness dan kesepian menunjukkan hubungan yang moderat dan signifikan $(r(5000)=-0,414 ; 95 \%$ CI $[-0,277 ;-0,540] ; p=0,000)$. Keempat, dimensi non-judgement dan kesepian menunjukkan hubungan negatif yang cenderung lemah dan signifikan $(r(5000)=-0,370 ; 95 \%$ CI $[-0,242 ;-0,486] ; p=0,000)$. Kelima, dimensi non-reactivity dan kesepian menunjukkan hubungan yang tidak signifikan $(r(5000)=-0,150 ; 95 \%$ CI $[0,018 ;-0,316] ; p=0,051)$.

\section{I S K U S I}

Hasil penelitian ini mendukung hipotesis yang dirumuskan, yaitu adanya hubungan negatif yang signifikan antara trait mindfulness dengan kesepian pada orang dewasa awal. Hubungan tersebut menunjukkan bahwa kedua variabel bergerak pada arah yang berlawanan, dengan kata lain peningkatan pada trait mindfulness diikuti dengan penurunan pada tingkat kesepian demikian pula sebaliknya. Hasil dari penelitian ini konsisten dengan penelitian lain yang serupa. Trait mindfulness ditemukan berkorelasi negatif secara signifikan dengan kesepian pada partisipan mahasiswa di China dengan usia antara 17-25 tahun (Jin dkk., 2020).

Hubungan negatif antara trait mindfulness dan kesepian dapat dipahami melalui beberapa cara. Pertama, trait mindfulness mendorong individu untuk membawa perhatiannya pada pengalaman masa sekarang dan mengambil sikap non-judgement. Helm (2019) menyebutkan bahwa kesepian terinisiasi ketika individu melakukan perbandingan sosial, baik dengan orang lain maupun dengan hubungan sosial dirinya sendiri di masa lampau. Trait mindfulness yang tinggi menurunkan ruminasi dan meningkatkan fleksibilitas kognitif (Glomb dkk., 2011). Langer (2014) juga menyatakan individu yang semakin mindful memiliki karakteristik berpikir dan kemampuan mengambil sudut pandang secara lebih luas, kontekstual, dan terbuka. Hal ini membuat individu mampu melepaskan diri dari ruminasi, 
dalam kaitannya dengan kesepian adalah individu dapat lebih mampu untuk melepaskan diri dari melakukan perbandingan sosial yang dapat menginisiasi atau bahkan memperburuk pengalaman kesepian. Berkaitan dengan pola berpikir yang lebih fleksibel dan terbuka, Bellucci (2020) menemukan kesepian berhubungan dengan kecenderungan untuk memiliki ekspektasi negatif bahwa orang lain kurang dapat dipercaya dan bersifat tidak adil dan adanya perhatian selektif terhadap ancaman sosial yang dapat memunculkan perilaku menghindar dari situasi sosial tersebut (Bangee dkk., 2014). Individu yang mindful akan lebih mampu untuk memonitor atensi secara lebih fleksibel dan terbuka dengan cara membawa perhatian pada pengalaman saat ini sehingga selain dapat melepaskan diri dari ekspektasi negatif, individu yang mindful dapat melakukan evaluasi terkait hubungan sosialnya dengan lebih akurat.

Kedua, kesepian menimbulkan reaksi fisiologis dan psikologis yang bersifat negatif, seperti peningkatan kortisol, tekanan darah, serta peningkatan stres dan kecemasan (Hawkley \& Cacioppo, 2010). Disisi lain trait mindfulness berdampak pada reduksi kondisi-kondisi tersebut (Tang dkk., 2007). Mindfulness juga dapat mengubah wilayah tertentu pada otak yaitu posterior cingulate cortex (PCC) dan precuneus yang terlibat dalam self-awareness (Tang \& Leve, 2016). Melalui kesadaran (awareness) akan sinyal-sinyal tubuh maupun ekspresi emosional tersebut, individu dapat meregulasi kondisi tersebut dan menurunkan perasaan kesepian atau setidaknya mengurangi ekspresi fisiologis maupun emosi yang ada.

Ketiga, trait mindfulness dapat meningkatkan self-compassion (Robins dkk., 2012). Individu dengan selfcompassion yang tinggi menunjukkan self-criticism yang rendah serta memiliki persepsi yang lebih tepat akan performa dirinya (Carlson, 2013). Oleh karena itu, melalui peningkatan penerimaan dan selfcompassion, mindfulness dapat mereduksi perasaan kesepian dengan cara membangun persepsi positif akan diri yang mana merupakan kondisi penting untuk melakukan interaksi sosial yang sukses dan sehat (Sha'ked \& Rokach, 2015).

Selain melakukan uji korelasi skor total mindfulness dengan kesepian, penelitian ini juga melakukan uji korelasi dimensi trait mindfulness. Beberapa dimensi yang diketahui tidak memiliki korelasi dengan kesepian adalah dimensi observe, dan non-reactivity. Sedangkan dimensi describe, act with awareness, dan non-judging memiliki korelasi dengan kesepian.

Tidak adanya hubungan antara dimensi observe dan non-reactivity dengan kesepian dapat disebabkan karena penelitian ini tidak memperhitungkan kondisi-kondisi lain yang biasanya muncul pada pengalaman kesepian yang mungkin relevan dengan kedua dimensi tersebut. Misalnya adalah kondisi kecemasan untuk dimensi non-reactivity. Sebuah penelitian menemukan peningkatan dimensi nonreactivity berhubungan dengan penurunan tingkat kecemasan (Hedman dkk., 2017). Demikian pula dengan dimensi observe, perasaan kesepian saja tidak berhubungan dengan kemampuan individu untuk mengamati dan memperhatikan stimulus internal maupun eksternal. Hal ini berarti individu mungkin masih mampu untuk mengamati (observe) berbagai pengalaman tersebut, akan tetapi dalam konteks mindfulness pengalaman tersebut mungkin saja tidak dipersepsikan dengan sikap penerimaan dan kesadaran utuh sebagaimana direfleksikan oleh dimensi non-judgement dan act with awareness.

Dimensi describe ditemukan hubungan negatif dengan kesepian. dengan kemampuan ini, individu akan mampu menggambarkan pengalamannya dengan kata-kata. Deskripsi yang dilakukan secara mindful akan merefleksikan aspek non-judgement. Disisi lain, individu yang kesepian memiliki distorsi kognitif ke arah negatif. Dengan demikian, pola kognitif negatif pada orang yang kesepian akan mendorong munculnya deskripsi yang bias. Kemudian, ditemukan juga hubungan negatif antara dimensi act with awareness dan non-judgement dengan kesepian. Kedua dimensi bersinggungan satu sama lain dalam kaitannya dengan kesepian. Hal ini dapat diartikan bahwa semakin kuat pengalaman kesepian yang 
dialami, semakin rendah kemampuan menjaga perhatian dan fokus pada pengalaman saat ini, serta semakin evaluatif penilaian individu terhadap diri dan orang lain, demikian pula sebaliknya. Selain itu, dibandingkan dengan mereka yang tidak kesepian, individu yang kesepian lebih sering mengingat informasi sosial negatif (Newall dkk., 2009).

\section{S I M P U L A N}

Temuan penelitian ini mengonfirmasi bahwa terdapat hubungan negatif antara trait mindfulness dan kesepian. Selain itu, berdasarkan hasil analisis korelasi masing-masing dimensi trait mindfulness dengan kesepian ditemukan bahwa dimensi describe, act with awareness, dan non-judgement berhubungan negatif dengan kesepian, sedangkan hubungan tidak ditemukan pada dimensi observe dan nonreactivity. Penelitian ini dilakukan dengan desain cross-sectional dan korelasional sehingga penjelasan hubungan kausalitas perlu dikonfirmasi melalui penelitian lebih lanjut. Selain itu, penelitian ini hanya menggunakan populasi dewasa awal sebagai partisipan penelitian. Penelitian selanjutnya dapat mengeksplorasi konteks lain sebagai sasaran penelitian, serta mengimplementasikan teknik pengambilan sampel yang lebih baik agar lebih mampu dalam merepresentasikan profil populasi yang digunakan.

\section{U C A P A N T E R I MAKASIH}

Penulis mengucapkan banyak terima kasih kepada seluruh responden atas partisipasinya dalam penelitian ini, serta kepada tim penguji atas saran yang telah diberikan, sehingga penulis dapat menyempurnakan penelitian ini.

\section{DEKLARASI POTENSI TERJADINYA KONFLIK KEPENTINGAN}

Muhammad Fahizza Amru dan Tri Kurniati Ambarini tidak bekerja, menjadi konsultan, memiliki saham, atau menerima dana dari perusahaan atau organisasi manapun yang mungkin akan mengambil untung dari diterbitkannya naskah ini.

\section{PUSTAKA ACUAN}

Akin, A. (2010). Self-compassion and Loneliness. International Online Journal of Educational Sciences, 2(3), 702-718.

Audinia, S. (2019). Hubungan kesepian dan gejala psikotik: Peran skema negatif sebagai mediator [Skripsi, Universitas Indonesia]. http://lib.ui.ac.id

Baer, R. A., Smith, G. T., \& Allen, K. B. (2004). Assessment of mindfulness by self-report: The Kentucky inventory of mindfulness skills. Assessment, 11(3), 191-206. https://doi.org/10.1177/1073191104268029 
Baer, R. A., Smith, G. T., Hopkins, J., Krietemeyer, J., \& Toney, L. (2006). Using Self-Report Assessment Methods to Explore Facets of Mindfulness. Assessment, 13(1), 27-45. https://doi.org/10.1177/1073191105283504

Bangee, M., Harris, R. A., Bridges, N., Rotenberg, K. J., \& Qualter, P. (2014). Loneliness and attention to social threat in young adults: Findings from an eye tracker study. Personality and Individual Differences, 63, 16-23. https://doi.org/10.1016/j.paid.2014.01.039

Bellucci, G. (2020). Positive attitudes and negative expectations in lonely individuals. Scientific Reports, 10(1), 18595. https://doi.org/10.1038/s41598-020-75712-3

Carlson, E. N. (2013). Overcoming the Barriers to Self-Knowledge: Mindfulness as a Path to Seeing Yourself as You Really Are. Perspectives on Psychological Science, 8(2), 173-186. https://doi.org/10.1177/1745691612462584

Coşan, D. (2014). An Evaluation of Loneliness. 103-110. https://doi.org/10.15405/epsbs.2014.05.13

Desk, N. (2020, November 5). COVID-19 pandemic changes friendships around globe. The Jakarta Post. https://www.thejakartapost.com/life/2020/11/05/covid-19-pandemic-changes-friendshipsaround-globe.html

Fourianalistyawati, E., Listiyandini, R. A., \& Fitriana, T. (2016). Hubungan Mindfulness dan Kualitas Hidup Orang Dewasa. Dalam Forum Ilmiah Psikologi Indonesia. Jakarta: Universitas Tarumanegara

Glomb, T. M., Duffy, M. K., Bono, J. E., \& Yang, T. (2011). Mindfulness at work. Research in Personnel and Human Resources Management, 115-157. https://doi.org/10.1108/S07427301(2011)0000030005

Gow, A. J., Pattie, A., Whiteman, M. C., Whalley, L. J., \& Deary, I. J. (2007). Social Support and Successful Aging: Investigating the Relationships Between Lifetime Cognitive Change and Life Satisfaction. Journal of Individual Differences., 28(3), 103-115. https://doi.org/10.1027/1614-0001.28.3.103

Hawkley, L. C., \& Cacioppo, J. T. (2010). Loneliness matters: A theoretical and empirical review of consequences and mechanisms. Annals of Behavioral Medicine: A Publication of the Society of Behavioral Medicine, 40(2), 218-227. https://doi.org/10.1007/s12160-010-9210-8

Hedman, E., Hesser, H., Andersson, E., Axelsson, E., \& Ljótsson, B. (2017). The mediating effect of mindful non-reactivity in exposure-based cognitive behavior therapy for severe health anxiety. Journal of Anxiety Disorders, 50, 15-22. https://doi.org/10.1016/j.janxdis.2017.04.007

Helm, P. J. (2019). Towards a Theory of Interpersonal Isolation: Adding Existential Isolation to the Mix [Doctoral

Dissertation,

The

University

of 
Arizona].https://repository.arizona.edu/bitstream/handle/10150/632994/azu_etd_17124_si p1_m.pdf?sequence=1

Horigian, V. E., Schmidt, R. D., \& Feaster, D. J. (2021). Loneliness, Mental Health, and Substance Use among US Young Adults during COVID-19. Journal of Psychoactive Drugs, 53(1), 1-9. https://doi.org/10.1080/02791072.2020.1836435

Hwang, T.-J., Rabheru, K., Peisah, C., Reichman, W., \& Ikeda, M. (2020). Loneliness and social isolation during the COVID-19 pandemic. International Psychogeriatrics, 32(10), 1217-1220. https://doi.org/10.1017/S1041610220000988

Jin, Y., Zhang, M., Wang, Y., \& An, J. (2020). The relationship between trait mindfulness, loneliness, regulatory emotional self-efficacy, and subjective well-being. Personality and Individual Differences, 154, 109650. https://doi.org/10.1016/j.paid.2019.109650

Langer, E. J. (2014). Mindfulness (2nd edition). Boston: Da Capo Lifelong Books.

Lim, M. H., Eres, R., \& Vasan, S. (2020). Understanding loneliness in the twenty-first century: An update on correlates, risk factors, and potential solutions. Social Psychiatry and Psychiatric Epidemiology, 55(7), 793-810. https://doi.org/10.1007/s00127-020-01889-7

Lindsay, E. K., Young, S., Brown, K. W., Smyth, J. M., \& Creswell, J. D. (2019). Mindfulness training reduces loneliness and increases social contact in a randomized controlled trial. Proceedings of the National Academy of Sciences of the United States of America, 116(9), 3488-3493. https://doi.org/10.1073/pnas.1813588116

Marchini, S., Zaurino, E., Bouziotis, J., Brondino, N., Delvenne, V., \& Delhaye, M. (2021). Study of resilience and loneliness in youth (18-25 years old) during the COVID-19 pandemic lockdown measures. Journal of Community Psychology, 49(2), 468-480. https://doi.org/10.1002/jcop.22473

Mare, Y. B. (2015). Pengaruh Terapi Aktivitas Kelompok (TAK) Sosialisasi Terhadap Tingkat Kesepian Pada Lansia Di Panti Werdha Hargodedali Surabaya [Skripsi]. Universitas Katolik Widya Mandala Surabaya.

Newall, N. E., Chipperfield, J. G., Clifton, R. A., Perry, R. P., Swift, A. U., \& Ruthig, J. C. (2009). Causal beliefs, social participation, and loneliness among older adults: A longitudinal study. Journal of Social and Personal Relationships, 26(2-3), 273-290. https://doi.org/10.1177/0265407509106718

Newman, B., \& Newman, P. (2015). Development Through Life: A Psychosocial Approach (Twelfth Edition). Cengage Learning. 
Peltzer, K., \& Pengpid, S. (2019). Loneliness correlates and associations with health variables in the general population in Indonesia. International Journal of Mental Health Systems, 13(1), 24. https://doi.org/10.1186/s13033-019-0281-z

Robins, C. J., Keng, S.-L., Ekblad, A. G., \& Brantley, J. G. (2012). Effects of mindfulness-based stress reduction on emotional experience and expression: A randomized controlled trial. Journal of Clinical Psychology, 68(1), 117-131. https://doi.org/10.1002/jclp.20857

Rocha, B. M. da, Rhodes, S., Vasilopoulou, E., \& Hutton, P. (2018). Loneliness in Psychosis: A Metaanalytical Review. Schizophrenia Bulletin, 44(1), 114-125. https://doi.org/10.1093/schbul/sbx036

Russell, D. W. (1996). UCLA Loneliness Scale (Version 3): Reliability, Validity, and Factor Structure. Journal of Personality Assessment, 66(1), 20-40. https://doi.org/10.1207/s15327752jpa6601_2

Sala, M., Rochefort, C., Lui, P. P., \& Baldwin, A. (2019). Trait Mindfulness and Health Behaviors: A Meta$\begin{array}{lllll}\text { Analysis. } \quad \text { Health } \quad \text { Review, } & 14, & 114 .\end{array}$ https://doi.org/10.1080/17437199.2019.1650290

Sha'ked, A., \& Rokach, A. (Eds.). (2015). Addressing Loneliness: Coping, Prevention and Clinical Interventions. Psychology Press. https://doi.org/10.4324/9781315774374

Sternberg, R. J. (2000). Images of Mindfulness. Journal of Social Issues, 56(1), 11-26. https://doi.org/10.1111/0022-4537.00149

Sundström, A., Adolfsson, A. N., Nordin, M., \& Adolfsson, R. (2020). Loneliness Increases the Risk of AllCause Dementia and Alzheimer's Disease. The Journals of Gerontology. Series B, Psychological Sciences and Social Sciences, 75(5), 919-926. https://doi.org/10.1093/geronb/gbz139

Tang, Y.-Y., \& Leve, L. D. (2016). A translational neuroscience perspective on mindfulness meditation as a prevention strategy. Translational Behavioral Medicine, 6(1), 63-72. https://doi.org/10.1007/s13142-015-0360-x

Tang, Y.-Y., Ma, Y., Wang, J., Fan, Y., Feng, S., Lu, Q., Yu, Q., Sui, D., Rothbart, M. K., Fan, M., \& Posner, M. I. (2007). Short-term meditation training improves attention and self-regulation. Proceedings of the National Academy of Sciences of the United States of America, 104(43), 17152-17156. https://doi.org/10.1073/pnas.0707678104

Weissbourd, R., Batanova, M., Lovison, V., \& Torres, E. (2021). How the Pandemic Has Deepened an Epidemic of Loneliness and What We Can Do About It (pp. 1-13). Harvard University. 